\title{
Sensory, Nutritional and Microbiological Characteristics of Fermented Finger Millet Beverage (Kunun-Tamba) Treated with Various Preservatives during Refrigerated Storage
}

\author{
Jubril B, Agarry 00* and Jubril M
}

Department of Microbiology, Faculty of Science, University of Abuja, Nigeria

Research Article

Volume 6 Issue 2

Received Date: March 17, 2021

Published Date: April 15, 2021

DOI: $10.23880 /$ fsnt-16000267

*Corresponding author: Agarry 00, Department of Microbiology, Faculty of Science, University of Abuja, Nigeria, Email: oluagarry@yahoo.com

\section{Abstract}

Six types of 'kunun-tamba' produced in this study using finger millet (Eleucine coracana L) were treated with (sodium benzoate, lime and lemon juice extracts singly or in combination) or without preservatives and evaluated for its microbiological (lactic acid bacteria-LAB), chemical and sensory quality characteristics throughout four weeks of refrigerated $\left(4^{\circ} \mathrm{C}\right)$ storage. The molecular characteristics of the seven (7) LABs isolated showed that Lactobacillus plantarum, Lactococcus lactis, Leuconostoc masenteroides, $L$ paeudo-mesenteroides and two (2) unidentified LABs were the predominant. The 'kunun-tamba' treated with $5 \mathrm{ml}$ lime+lemon showed a low LAB count $\left(\log _{10} 0.86-1.25 \mathrm{cfu} / \mathrm{ml}\right), \mathrm{pH}(3.90-4.08)$ and sensory attributes (taste: 6.7-6.9, appearance: 6.6-6.9, aroma: 6.1-6.8) evaluated throughout the study period ( 4 weeks) which differed $(\mathrm{p}<0.05)$ from those of the other products produced in this study. The results of this study shows that the use of the combinations of lime and lemon $(5 \mathrm{ml})$ natural preservatives gave a better shelf stable product than an artificial preservative (sodium benzoate) and therefore could be a suitable alternative meeting consumers aspiration for replacement of artificial preservatives with natural ones.

Keywords: Kunun-Tamba; Lactic Acid Bacteria; Natural Preservatives; Shelf-Life Storage; Sensory Evaluation

\section{Introduction}

'Kunun-tamba' is a local fermented non-alcoholic cereal beverage produced from finger millet grain (Eleusine coracana, L) commonly sold in Gwagwalada, Federal Capital Territory (FCT) Nigeria. Finger millet grains are generally rich in minerals such as calcium, phosphorus, magnesium, potassium, manganese and thiamine as compared to other species of millets [1]. The production of 'kunun-tamba' and likewise other types of kunun (kunun-zaki, kunun-gyada, kunun-tsamiya, kunun-baule, kunun-jiko, kunun-gayamba) are similar. Kunun-zaki has been described by other workers as an ethnic fermented food [2]. According to Tamang [3] ethnic fermented foods are foods produced by ethnic people using native knowledge such aas grains and natural occurring microbial cultures. Every community across the world has its distinct food culture which symbolizes its cultural heritage, also, geographical locations, environmental factors as well as available plant and animal sources characteristically symbolizes the culture of a people thereby bringing people of different background together [3-5].

Several studies have indicated kunun-zaki as important drinks with immense social, economic, nutritional and medicinal importance to its numerous consumers [6,7], however, because of its high moisture content, kunun-zaki 


\section{Food Science \& Nutrition Technology}

has a limited shelf-life of about $24 \mathrm{~h}$ after production and attempts has been made by several workers to extend its shelf-life using combinations of pasteurization and chemical preservatives for 4 days (ambient storage) and 14 days (refrigerated storage) without any observed deleterious effect on its sensory attributes $[8,9]$. Other studies produced powdered kunun-zaki thereby extending its shelf-life beyond 14 days $[10,11]$.

Preservatives have been used over the years to extend the shelf-life of foods and the food industry has invested more in preservation methods [12]. However, consumers nowadays are becoming aware of the adverse effects that these synthetic chemical preservatives can cause to consumers' health and therefore requires that these preservatives be replaced with natural ones [12]. Research is ongoing to looking for preservatives agents considered natural (from plant) that could possibly extend the shelf-life and ensuring safety of foods [13]. The study is aimed at assessing the sensory, nutritional and microbiological qualities of fermented beverage kunun-tamba treated with natural and artificial preservatives during refrigerated storage.

\section{Materials and Methods}

\section{Study Area}

This study was carried out at Gwagwalada $\left(8.9508^{\circ} \mathrm{N}\right.$, $7.0767^{\circ} \mathrm{E}$ ) in the Federal Capital Territory, (FCT) Abuja, Nigeria.

\section{Sample Collection}

Finger millet (Eleusine coracana, L) seeds, ginger, lemon, lime, dried sweet potatoes and spices (cloves, ginger and black pepper) were randomly purchased from retailers within Gwagwalada market.

\section{Preparation and Sterilization of Stock Preservatives}

The methods described by Fapohunda \& Adeware [14] were used to prepare the various preservatives regimes (sodium benzoate, lemon and lime juice extracts) used in this study.

\section{a) Sodium Benzoate}

Two grams (2g) of sodium benzoate was dissolved in $2 \mathrm{ml}$ of sterile distilled water, mixed thoroughly and filter sterilized using PALL Acrodice Membrane Filtration Unit $(0.2 \mu \mathrm{m}$, Supor Membrane), this was transferred to $20 \mathrm{ml}$ sterilized universal bottle and stored in the refrigerator $\left(4 \pm 2^{\circ} \mathrm{C}\right)$.

\section{b) Lemon Juice Extract}

Six lemon fruits were washed thoroughly then cut with sterile knife (sterilized with $5 \%$ sodium metabisulphite and rinsed severally with sterile water) into two halves following which $20 \mathrm{ml}$ of the juice were squeezed out and asceptically filtered using Supor membrane filtration unit and transferred to a $50 \mathrm{ml}$ sterile corked conical flask and stored at the refrigerator.

\section{c) Lime Juice Extract}

A similar procedure described in (ii) above was used to obtain $20 \mathrm{ml}$ of lime juice extract

\section{Production of Finger Millet Beverage (Kunun Tamba)}

'Kunun-tamba' was produced using the methods of kunun-zaki production as described by Akoma, et al. [15] using finger millet. The process involves cleaning and steeping of the grains before addition of spices (mixture of cloves, ginger and black pepper) and wet milling. $500 \mathrm{~g}$ of cleaned grains were steeped in $1000 \mathrm{ml}$ tap water $(1: 2$, $\mathrm{w} / \mathrm{v})$ for $24 \mathrm{~h}$ at ambient temperature $\left(30-32^{\circ} \mathrm{C}\right)$. The water was then decanted off and the grains washed with more tap water before wet milling with $10 \mathrm{~g}$ of spices in 2 volume tap water. The paste, about $800 \mathrm{~g}$, was divided into two portions $(1: 3, v / v)$. One of these was cooked using 2 volume of boiling water and allowed to cool to $45^{\circ} \mathrm{C}$. $2 \mathrm{~g}$ of ground dried sweet potato was mixed separately with the remaining uncooked paste $(1: 4, \mathrm{w} / \mathrm{w})$ before being added to the cooked paste (i.e. gelatinized starch at $45^{\circ} \mathrm{C}$ ). This mixture was stirred vigorously for about $5 \mathrm{~min}$ and then allowed to ferment for 8-10h to produce 'kunun-tamba' following sieving (mesh size approx. $350 \mu \mathrm{m}$ ) to remove the pomace.

\section{Incorporation of Preservatives to 'Kunun- Tamba' and Shelf-Life Studies}

Following production of 'kunun-tamba' described (d) above, the various preservatives prepared in (c) were added each singly or in combination and stored in the refrigeration $\left(4^{\circ} \mathrm{C}\right)$ throughout 28 days storage period.

i. $2 \mathrm{ml}$ of the sodium benzoate was added $100 \mathrm{ml}$ of 'kununtamba' in a $150 \mathrm{ml}$ sterile corked conical flask, mixed thoroughly and stored.

ii. $5 \mathrm{ml}$ of lime juice extract was added to $100 \mathrm{ml}$ 'kununtamba' in a $150 \mathrm{ml}$ sterile corked conical flask, shake and stored.

iii. $5 \mathrm{ml}$ of lime juice extract was added $100 \mathrm{ml}$ of 'kununtamba' as described earlier.

iv. $2.5 \mathrm{ml}$ each of lemon and lime juice extract were added in combination as $100 \mathrm{ml}$ of 'kunun-tamba' in a $150 \mathrm{ml}$ sterile corked conical flask shaken and stored in a 


\section{Food Science \& Nutrition Technology}

refrigerator $\left(4^{\circ} \mathrm{C}\right)$.

v. $5.0 \mathrm{ml}$ each of lemon and lime juice extracts were added in combination and treated and described in (iv) above.

vi. A control sample was prepared using $100 \mathrm{ml}$ of 'kununtamba' in sterile corked $150 \mathrm{ml}$ conical flask without addition of preservatives and stored in a refrigerator

\section{Bacteriological Analysis}

The lactic acid bacteria (LAB) associated with 'kununtamba' production were isolated following enrichment techniques using Brain Heart Infusion (BHI) broth and $0.002 \%$ sodium azide as described by Agarry et al. [16] with subsequent purification of $L A B$ isolates and subcultures on MRS agar and slants. Identification of LAB isolates was based on convectional techniques (Gram staining, cultural and biochemical characteristics) as described by Agarry, et al. [16] and molecular sequencing technique (DNA extraction, PCR and sequencing of PCR products) as described by Kim, et al. [17]. The amplicons were sequenced using only the $27 \mathrm{~F}$ primer by the next-generation sequencing techniques by Eurofin MWG Operon USA. The sequences were then analyzed using CLC-bio Genomics Workbench software (Eurofin, MWG Operon USA). The sequences that were obtained were blasted using the BLAST alignment software in order to determine the homology with sequences of reference strains in the GENBANK (Genome Database of the National Center for Biotechnology Information); following which the sequences were analyzed on two separate platforms/databases-website NCBI and website RPD, www. ncbi.nlm.nih.gov. All the analysis was conducted by Applied Biotech International Laboratory, Abuja Nigeria.

\section{Ph and Titratable Acidity}

The pH of 'kunun-tamba' was determined weekly in triplicates throughout storage using pH meter (Jenway 3510 $\mathrm{pH}$ Meter) after standardization with $\mathrm{pH} 4$ and $\mathrm{pH} 7$ buffers (BDH, England). The titratable acidity of 'kunun-tamba' was determined weekly in triplicates throughout storage by titrating $10 \mathrm{ml}$ of the sample with $0.1 \mathrm{~N}$ sodium hydroxide to phenolphthalein end point (pink). The titratable acidity (\% lactic acid) was calculated for each sample as described by Field [18].

\section{Proximate Analysis}

The moisture content, crude protein, crude fat and ash contents of the freshly prepared 'kunun-tamba' samples were determined in triplicates as described by AOAC [19].

\section{Mineral Analysis}

The mineral contents (calcium, magnesium and phosphorous) of freshly prepared 'kunun-tamba' samples was determined in triplicates as described by AOAC [19]. Magnesium and calcium were determined using Atomic Absorption Spectrophotometer (Buck Scientific, USA; Accusy 211); while phosphorus were determined using Jenwa Flame Photometer (UK, PF P7) and Jenwa Colorimeter (UK, Spectronic, 20) respectively.

\section{Organoleptic Analysis}

The overall quality acceptability of stored 'kunun-tamba' produced in this study were evaluated weekly by 50 -member taste panelists comprising of some trained students and lecturers of the Department of Microbiology, University of Abuja, Abuja who are familiar with the product using a 7-point hedonic scale (where $7=$ like extremely; $6=$ like very much; 5 = like slightly; $4=$ neither like nor dislike; $3=$ dislike slightly; 2 = dislike very much and $1=$ dislike extremely) as described by Stone $\&$ Sidel [20]. The same sets of 50 -member taste panelists were used throughout the storage period to evaluate the sensory quality attributes (appearance, taste, aroma and overall acceptability) of the products.

\section{Statistical Analysis}

Analysis of variance (ANOVA) was carried out for the LAB counts, $\mathrm{pH}$, titratable acidity, proximate, mineral and sensory scores of 'kunun-tamba' produced in this study. The mean scores were computed and significant differences among the mean was determined (Duncan, $\mathrm{p}=0.05$ ) using Statistical Packages for Social Sciences (SPSS) for Windows version 20.

\section{Results}

\section{Identification of bacteria isolates from kunu tamba}

Total lactic acid bacteria (LAB) count: The LAB count $\left(\log _{10}\right.$ $\mathrm{cfu} / \mathrm{ml}$ ) of preserved kunun tamba during 4 weeks of storage is shown in Table 1 . The kunun tamba with no preservatives added in week one was higher (4.20) and significantly different $(\mathrm{p}<0.05)$ from the other kunun tamba treated with sodium benzoate (1.08), lime (1.93), lemon (1.25) or their combinations (1.25). Again, in week two, the unpreserved kunun tamba had higher LAB count (3.78) and significantly different $(\mathrm{p}<0.05)$ from the rest products, a similar trend was observed throughout the storage period (Table 1). 


\begin{tabular}{|c|c|c|c|c|}
\hline \multirow{2}{*}{ Product } & \multicolumn{4}{|c|}{ LAB count $\log _{10}$ cfu/Storage periods ${ }^{1,2}$} \\
\hline & WEEK1 & WEEK2 & WEEK3 & WEEK4 \\
\hline k-tamba without preservatives & $4.20 \pm 0.50^{\mathrm{a}}$ & $3.78 \pm 0.50^{\mathrm{a}}$ & $4.00 \pm 1.00^{\mathrm{a}}$ & $3.00 \pm 1.00^{\mathrm{a}}$ \\
\hline k-tamba+2ml-NaB & $1.08 \pm 0.50^{\mathrm{b}}$ & $2.48 \pm 8.50^{\mathrm{b}}$ & $1.28 \pm 2.50^{\mathrm{d}}$ & $1.85 \pm 2.00^{\mathrm{c}}$ \\
\hline k-tamba+2.5ml (lime+lemon) & $0.45 \pm 1.00^{\mathrm{c}}$ & $1.01 \pm 1.60^{\mathrm{d}}$ & $1.71 \pm 1.05^{\mathrm{c}}$ & $2.15 \pm 1.15^{b}$ \\
\hline k-tamba+5ml (lime+lemon) & $1.25 \pm 0.00^{\mathrm{b}}$ & $0.86 \pm 1.50^{\mathrm{e}}$ & $0.98 \pm 1.50^{\mathrm{e}}$ & $1.70 \pm 0.50^{\mathrm{d}}$ \\
\hline k-tamba+5ml-lemon & $1.25 \pm 0.50^{\mathrm{b}}$ & $1.23 \pm 2.50^{\mathrm{c}}$ & $0.50 \pm 3.00^{\mathrm{e}}$ & $1.75 \pm 0.50^{\mathrm{d}}$ \\
\hline k-tamba+5ml-lime & $1.93 \pm 0.50^{\mathrm{b}}$ & $0.95 \pm 1.00^{\mathrm{e}}$ & $1.90 \pm 1.00^{\mathrm{b}}$ & $1.93 \pm 0.00^{\mathrm{c}}$ \\
\hline
\end{tabular}

Table 1: LAB count of kunun-tamba during storage.

${ }^{1}$ Each value is the mean \pm standard error of triplicate determinations

${ }^{2}$ Different letters within the same column are significantly different $(\mathrm{p}<0.05)$.

Characterization of LAB Isolated from Kunu Tamba: As shown in Table 2, five of the LABs isolated (L01-L03, L06 and L07) in this study were cocci while the remaining two LAB isolates (L04-L05) were rod shape. Based on genomic analysis on ten species of LAB isolated in this study were two lactobacillus spp., four leuconostoc spp., two lactococcus and two unidentified LAB were found to be dominant in the kunun tamba.

\begin{tabular}{|c|c|c|c|c|c|c|c|}
\hline \multirow{2}{*}{ Test } & \multicolumn{7}{|c|}{ Isolates } \\
\hline & L01 & L02 & L03 & L04 & L05 & L06 & L07 \\
\hline Morphology & Cocci & Cocci & Cocci & Rod & Rod & Cocci & cocci \\
\hline Cultural characteristics & $\mathrm{P} /$ point & $\mathrm{P} /$ point & $\mathrm{P} /$ point & $\mathrm{P} /$ point & P/point & $\mathrm{P} /$ point & $\mathrm{P} /$ point \\
\hline Gram reaction & + & + & + & + & + & + & + \\
\hline Catalase & - & - & - & - & - & - & - \\
\hline Hot loop & + & - & + & + & - & - & + \\
\hline Production gas from glucose & + & + & + & - & - & - & + \\
\hline \multicolumn{8}{|l|}{ Sugar fermentation } \\
\hline Glucose & + & + & + & + & + & + & + \\
\hline Maltose & + & + & + & + & + & + & + \\
\hline Sucrose & + & + & + & + & + & + & + \\
\hline Galactose & + & + & + & + & + & + & + \\
\hline Ribose & + & + & + & + & + & + & + \\
\hline Mannose & - & - & - & + & + & - & - \\
\hline Lactose & - & - & - & - & + & + & - \\
\hline Xylose & + & - & + & - & + & + & - \\
\hline d-xylose & + & + & + & - & - & - & + \\
\hline d-fructose & + & + & + & + & + & + & + \\
\hline Sorbitol & - & - & - & - & + & - & - \\
\hline Amygdalin & - & - & - & + & + & + & - \\
\hline Esculin & + & + & + & + & + & + & + \\
\hline Salicin & - & - & - & + & + & + & - \\
\hline Cellobiose & - & - & - & + & + & + & - \\
\hline Trehalose & + & + & + & + & + & + & + \\
\hline Gluconate & + & + & + & + & + & - & - \\
\hline Inulin & + & + & + & - & - & - & - \\
\hline
\end{tabular}

Table 2: Morphological and biochemical characteristics of lactic acid bacteria isolated from kunun-tamba. $\mathrm{P} /$ point=pin point colony.

The amplicons (1-10) that were sequenced using only the $27 \mathrm{~F}$ primer by the next generation sequencing technique by eurofin MWG Operon USA. Were analyzed using basic local alignment search tool (BLAST) shown in Table 3. L01 at species level was Leuconostoc mesenteriodes query percentage of $86 \%$, L02 were unidentified LAB and L03 
was identified as Leuconostoc pseudo mesenteroides query percentage of $95 \%$. L04 had no similarity on the NCBI data base. L05 was identified as lactobacillus plantarum at specie level with query percentage of $86 \%$, L06 was identified as Lactococcus lactis query percentage of $94 \%$ (Table 3).

\begin{tabular}{|c|c|c|c|c|c|}
\hline Sample & Phylogenetic identification/rank & Query & E value & Identity & Accession \\
\hline NE-01L_27F & Leuconostoc mesenteroides & $81 \%$ & $1.00 \mathrm{E}-53$ & $86 \%$ & AB830325.1 \\
\hline NE-02L_27F & No similarity found & N/A & N/A & N/A & N/A \\
\hline NE-03L_27F & $\begin{array}{c}\text { Leuconostoc pseudo mesenteroides strain } \\
\text { NWAFU4001 }\end{array}$ & $42 \%$ & $4.00 \mathrm{E}-57$ & $95 \%$ & MG462044.1 \\
\hline NE-04L_27F & No similarity found & N/A & N/A & N/A & N/A \\
\hline NE-05L_27F & Lactobacillus plantarum strain 14RA5914 & $39 \%$ & $9.00 \mathrm{E}-69$ & $82 \%$ & CP023001.1 \\
\hline NE-06L_27F & Lactococcus lactis & $94 \%$ & $1.00 \mathrm{E}-52$ & $86 \%$ & AB950385.1 \\
\hline
\end{tabular}

Table 3: Molecular characteristics of LAB isolates.

\section{Chemical quality characteristics of kunun tamba during storage}

pH: Generally, the kunun tamba treated with sodium benzoate had higher $\mathrm{pH}$ values (6.11-6.70) which were significantly different $(\mathrm{p}<0.05)$ from the rest products throughout the storage period (4 weeks). But the kunun tamba treated with $5 \mathrm{ml}$ lime+lemon (3.90-4.08) and $5 \mathrm{ml}$ lime (3.94-4.10) consistently showed a low $\mathrm{pH}$ values throughout the storage period (Table 4).

\begin{tabular}{|c|c|c|c|c|}
\hline \multirow[b]{2}{*}{ Products/treatment } & \multicolumn{4}{|c|}{ Storage periods ${ }^{1,2}$} \\
\hline & Week 1 & Week 2 & Week 3 & Week 4 \\
\hline k-tamba without preservatives & $4.67 \pm 0.05^{b}$ & $4.53 \pm 0.01^{\mathrm{b}}$ & $4.36 \pm 0.02^{\mathrm{b}}$ & $4.36 \pm 0.02^{b}$ \\
\hline k-tamba+2ml-NaB & $6.70 \pm 0.02^{a}$ & $6.20 \pm 0.02^{a}$ & $6.11 \pm 0.02^{\mathrm{a}}$ & $6.11 \pm 0.02^{\mathrm{a}}$ \\
\hline k-tamba+2.5ml (lime+lemon) & $4.58 \pm 0.02^{\mathrm{c}}$ & $4.51 \pm 0.01^{\mathrm{b}}$ & $4.26 \pm 0.02^{\mathrm{c}}$ & $4.26 \pm 0.02^{\mathrm{cd}}$ \\
\hline k-tamba+5ml (lime+lemon) & $4.08 \pm 0.01^{\mathrm{e}}$ & $4.01 \pm 0.01^{\mathrm{d}}$ & $3.90 \pm 0.02^{\mathrm{d}}$ & $3.90 \pm 0.02^{\mathrm{e}}$ \\
\hline k-tamba+5ml-lemon & $4.51 \pm 0.01^{\mathrm{d}}$ & $4.40 \pm 0.01^{\mathrm{c}}$ & $4.30 \pm 0.01^{\mathrm{b}}$ & $4.30 \pm 0.01^{\mathrm{bc}}$ \\
\hline k-tamba+5ml-lime & $4.10 \pm 0.01^{\mathrm{e}}$ & $4.01 \pm 0.02^{\mathrm{d}}$ & $3.94 \pm 0.02^{\mathrm{d}}$ & $3.94 \pm 0.02^{\mathrm{e}}$ \\
\hline
\end{tabular}

Table 4: $\mathrm{pH}$ of kunun-tamba during storage.

${ }^{1}$ Each value is the mean \pm standard error of triplicate determinations

${ }^{2}$ Different letters within the same column are significantly different $(\mathrm{p}<0.05)$

Titratable Acidity: As shown in Table 5, the titratable acidity (\% lactic acid) of kunun tamba treated with sodium benzoate and $2.5 \mathrm{ml}$ lime+lemon and $5 \mathrm{ml}$ lemon were higher $(0.26)$ and these differed $(\mathrm{p}<0 / 05)$ from the rest product on week one, however, in week two, the kunun tamba treated with $5 \mathrm{ml}$ lime+lemon were higher $(0.45)$ and significantly different $(\mathrm{p}<0.05)$ from the other products.

\begin{tabular}{|c|c|c|c|c|}
\hline \multirow{2}{*}{ PRODUCT } & \multicolumn{4}{|c|}{ Storage periods ${ }^{1,2}$} \\
\hline & WEEK1 & WEEK2 & WEEK3 & WEEK4 \\
\hline k-tamba without preservatives & $0.25 \pm 0.01^{b}$ & $0.41 \pm 0.01^{b}$ & $0.53 \pm 0.01^{b}$ & $0.65 \pm 0.01^{b}$ \\
\hline $\mathrm{k}$-tamba+2ml-NaB & $0.26 \pm 0.01^{\mathrm{a}}$ & $0.39 \pm 0.01^{\mathrm{c}}$ & $0.49 \pm 0.01^{\mathrm{c}}$ & $0.60 \pm 0.01^{\mathrm{c}}$ \\
\hline k-tamba+2.5ml (lime+lemon) & $0.26 \pm 0.01^{\mathrm{a}}$ & $0.42 \pm 0.01^{b}$ & $0.53 \pm 0.01^{b}$ & $0.63 \pm 0.01^{b}$ \\
\hline k-tamba+5ml (lime+lemon) & $0.23 \pm 0.01^{\mathrm{c}}$ & $0.45 \pm 0.01^{\mathrm{a}}$ & $0.54 \pm 0.01^{b}$ & $0.74 \pm 0.01^{\mathrm{a}}$ \\
\hline k-tamba +5 ml-lemon & $0.26 \pm 001^{\mathrm{a}}$ & $0.42 \pm 0.01^{\mathbf{b}}$ & $0.63 \pm 0.01^{\mathrm{a}}$ & $0.73 \pm 0.01^{\mathrm{a}}$ \\
\hline k-tamba+5ml-lime & $0.23 \pm 0.01^{\mathrm{c}}$ & $0.33 \pm 0.01^{\mathrm{d}}$ & $0.41 \pm 0.01^{\mathrm{d}}$ & $0.62 \pm 0.01^{b}$ \\
\hline
\end{tabular}

Table 5: Titratable acidity (\% lactic acid) of kunun-tamba during storage.

${ }^{1}$ Each value is the mean \pm standard error of triplicate determinations

${ }^{2}$ Different letters within the same column are significantly different $(\mathrm{p}<0.05)$ 
Also, in week 3 , the kunun tamba treated with $5 \mathrm{ml} \mathrm{lemon}$ had a higher titratable acidity $(0.63)$ which differed $(p<0.05)$ from the other kunun tambas' produced in this study. In week 4, the kunun tambas' treated with $5 \mathrm{ml}$ lemon and the combinations of lime+lemon $(5 \mathrm{ml})$ were both higher $(0.73$ and 0.74 respectively) and these differed $(p<0.05)$ from the other products. Furthermore, the kunun tamba treated with sodium benzoate had the lest titratable acidity in weeks 2-4
$(0.39,0.49$ and 0.60 respectively).

\section{Chemical composition of kunu tamba \\ a) Proximate content}

In Table 6 is shown the proximate composition of six kunun tambas produced in this study. The moisture content (\%) which ranged from 88.14-90.49 showed that there were no significant differences $(p>0.05)$ in their moisture content.

\begin{tabular}{|c|c|c|c|c|c|c|}
\hline \multirow{2}{*}{ Product/treatments } & \multicolumn{6}{|c|}{ Proximate composition $(\%)^{1,2}$} \\
\hline & Moisture & Ash & Crude fat & Crude protein & $\mathrm{C} / \mathrm{H}_{2} \mathbf{O}$ & Crude fibre \\
\hline k-tamba without preservatives & $89.72 \pm 0.45^{a}$ & $1.78 \pm 0.09^{\mathrm{d}}$ & $0.3 \pm 0.02^{\mathrm{a}}$ & $1.15 \pm 0.05^{\mathrm{c}}$ & $7.95 \pm 0.3^{b}$ & $13.1 \pm 0.01^{\mathrm{a}}$ \\
\hline k-tamba+2ml-NaB & $88.28 \pm 0.93^{\mathrm{a}}$ & $1.92 \pm 0.11^{\mathrm{c}}$ & $0.36 \pm 0.02^{\mathrm{a}}$ & $1.83 \pm 0.21^{\mathrm{a}}$ & $9.87 \pm 0.83^{\mathrm{a}}$ & $9.87 \pm 0.02^{\mathrm{d}}$ \\
\hline k-tamba+2.5ml (lime+lemon) & $89.73 \pm 0.42^{\mathrm{a}}$ & $1.94 \pm 0.09^{c}$ & $0.28 \pm 0.05^{\mathrm{a}}$ & $1.64 \pm 0.11^{\mathrm{a}}$ & $7.55 \pm 0.05^{\mathbf{b}}$ & $12.72 \pm 0.02^{\mathrm{b}}$ \\
\hline k-tamba+5ml (lime+lemon) & $90.49 \pm 0.05^{a}$ & $2.55 \pm 0.44^{\mathrm{a}}$ & $0.1 \pm 0.01^{\mathrm{c}}$ & $1.62 \pm 0.07^{b}$ & $6.64 \pm 0.04^{c}$ & $11.28 \pm 0.04^{\mathrm{c}}$ \\
\hline k-tamba+5ml-lemon & $89.63 \pm 0.36^{\mathrm{a}}$ & $2.18 \pm 0.5^{b}$ & $0.24 \pm 0.06^{\mathbf{b}}$ & $1.62 \pm 0.11^{b}$ & $7.58 \pm 0.37^{\mathbf{b}}$ & $8.31 \pm 0.15^{\mathrm{e}}$ \\
\hline k-tamba+5ml-lime & $88.14 \pm 0.05^{\mathrm{a}}$ & $2.5 \pm 0.01^{\mathrm{a}}$ & $0.18 \pm 0.05^{c}$ & $1.16 \pm 0.02^{\mathrm{a}}$ & $6.43 \pm 0.04^{c}$ & $8.44 \pm 0.12^{\mathrm{e}}$ \\
\hline
\end{tabular}

Table 6: Proximate composition of kunun tamba.

${ }^{1}$ Each value is the mean \pm standard error of triplicate determinations

${ }^{2}$ Different letters within the same subset column are significantly different $(\mathrm{p}<0.05)$

The ash content (\%) of the kunun tamba treated with lime $(5 \mathrm{ml})$, lime+lemon $(5 \mathrm{ml})$ did not differ $(p>0.05)$ but these differed $(p<0.05)$ from the ash contents of the rest products (Table 6). Also, the crude fat of the kunun tamba treated with no preservative $(0.30)$, sodium benzoate $(0.36)$, $2.5 \mathrm{ml}$ lime+lemon (0.28) were not significantly different $(p>0.05)$ but these differed $(p<0.05)$ from the ash content of the other products (Table 6).

There were no significant difference $(p>0.05)$ in the crude protein content of the kunun tamba treated with sodium benzoate (1.83), $2.5 \mathrm{ml}$ lime+lemon (1.64) and $5 \mathrm{ml}$ lime (1.16), but, these differed $(\mathrm{p}<0.05)$ from those of $5 \mathrm{ml}$ lime+lemon (1.62), $5 \mathrm{ml}$ lemon (1.62) and kunun tamba without any preservatives added (1.15). Furthermore, the carbohydrate content of the kunun tamba treated with sodium benzoate (9.87) and crude fibre content of the unpreserved kunun tamba (13.10) were observed to be higher and significantly different $(\mathrm{p}<0.05)$ from those of the other products (Table 6).

\section{b) Mineral content}

In Table 7 is shown the calcium content of the six kunun tambas produced in this study $(3.89-5.64 \mathrm{mg} / 100 \mathrm{~g})$, the kunun tamba treated with $5 \mathrm{ml}$ lime+lemon was observed to have a higher calcium content (5.64) which differed from the rest product.

\begin{tabular}{|c|c|c|c|}
\hline \multirow{2}{*}{ Product/treatments } & \multicolumn{3}{|c|}{ Mineral composition (mg/100g) ${ }^{1,2}$} \\
\hline & Calcium & Magnesium & Phosphorus \\
\hline k-tamba without preservatives & $3.89 \pm 0.14^{\mathrm{d}}$ & $19.57 \pm 0.45^{c}$ & $37.03 \pm 0.19^{c}$ \\
\hline $\mathrm{k}$-tamba+2ml-NaB & $4.17 \pm 0.15^{d}$ & $18.01 \pm 0.05^{\mathrm{d}}$ & $26.45 \pm 0.59^{d}$ \\
\hline k-tamba+2.5ml (lime+lemon) & $4.69 \pm 0.31^{\mathrm{c}}$ & $17.19 \pm 0.11^{\mathrm{e}}$ & $40.07 \pm 0.07^{\mathbf{b}}$ \\
\hline k-tamba+5ml (lime+lemon) & $5.64 \pm 0.47^{\mathrm{a}}$ & $19.45 \pm 0.95^{c}$ & $45.41 \pm 0.54^{\mathrm{a}}$ \\
\hline k-tamba+5ml-lemon & $4.94 \pm 0.27^{\mathbf{b c}}$ & $19.84 \pm 0.19^{b}$ & $26.19 \pm 0.15^{d}$ \\
\hline k-tamba $+5 \mathrm{ml}$-lime & $5.04 \pm 0.21^{\mathbf{b}}$ & $21.04 \pm 0.15^{\mathrm{a}}$ & $39.09 \pm 0.12^{\mathbf{b}}$ \\
\hline
\end{tabular}

Table 7: Mineral composition of Kunun tamba.

${ }^{1}$ Each value is the mean \pm standard error of triplicate determinations

${ }^{2}$ Different letters within the same subset column are significantly different $(\mathrm{p}<0.05)$ 
Also, the magnesium content $(17.19-21.04 \mathrm{mg} / 100 \mathrm{~g})$ of the kunun tamba treated with $5 \mathrm{ml}$ lime was higher $(21.04 \mathrm{mg} / 100 \mathrm{~g})$ and significantly different $(\mathrm{p}<0.05)$ from the magnesium content of the other products. Furthermore, the phosphorus content of kunun tamba treated with $5 \mathrm{ml}$ lime+lemon $(45.41 \mathrm{mg} / 100 \mathrm{~g})$ was higher and significantly different $(\mathrm{p}<0.05)$ from the other kunun tambas produced in this study (Table 7).

\section{c) Sensory quality}

In Table 8 is shown the sensory quality attributes (appearance, taste, aroma) of the six kunun-tamba produced in this study during four weeks of storage. There were no significant differences $(p>0.05)$ in the appearance (6.7-6.9), taste (6.6-6.8) and aroma (6.6-6.9) at end of the first week of storage. However, in weeks 2, 3 and 4 of the storage period, the kunun tamba treated with $5 \mathrm{ml}$ lime+lemon were observed to be generally acceptable in all the quality attributes evaluated and differed $(\mathrm{p}<0.05)$ from the other products (Table 8$)$.

\begin{tabular}{|c|c|c|c|c|c|c|c|c|c|c|c|c|}
\hline \multicolumn{13}{|c|}{ Storage period (weeks) } \\
\hline & \multicolumn{3}{|c|}{ One } & \multicolumn{3}{|c|}{ Two } & \multicolumn{3}{|c|}{ Three } & \multicolumn{3}{|c|}{ Four } \\
\hline $\begin{array}{c}\text { Product/ } \\
\text { Treatment }\end{array}$ & App & Taste & Aro & App & Taste & Aro & App & Taste & Aro & App & Taste & Aro \\
\hline $\begin{array}{c}\text { Kunun tamba } \\
\text { without } \\
\text { preservatives }\end{array}$ & $6.9 \pm 0.7 a$ & $6.7 \pm 0.8 \mathrm{a}$ & $6.9 \pm 1.2 \mathrm{a}$ & $6.3 \pm 1.1 \mathrm{~b}$ & $5.0 \pm 0.9 \mathrm{~d}$ & $5.9 \pm 0.4 c$ & $5.3 \pm 1.0 \mathrm{c}$ & $4.9 \pm 0.7 \mathrm{~d}$ & $\mathrm{~d} 4.0 \pm 0.5 \mathrm{~d}$ & $4.9 \pm 0.9 \mathrm{e}$ & $4.4 \pm 0.6 \mathrm{f}$ & $\mathrm{f} \mid 5.6 \pm 0.1 \mathrm{~d}$ \\
\hline $\begin{array}{c}\text { Kunun tamba } \\
+2 \mathrm{ml}-\mathrm{NaB} \\
\end{array}$ & $6.8 \pm 1.1 \mathrm{a}$ & $6.7 \pm 0.6 \mathrm{a}$ & $6.9 \pm 0.8 \mathrm{a}$ & $6.4 \pm 1.1 \mathrm{~b}$ & $7.0 \pm 0.7 a$ & $6.8 \pm 0.6 a$ & $5.8 \pm 0.8 \mathrm{~b}$ & $5.5 \pm 0.7 \mathrm{~b}$ & $5.6 \pm 0.4 \mathrm{c}$ & $5.1 \pm 0.6 \mathrm{~d}$ & $5.3 \pm 0.9 \mathrm{e}$ & $6.0 \pm 0.5 \mathrm{c}$ \\
\hline $\begin{array}{c}\text { Kunun tamba } \\
+2.5 \mathrm{ml} \\
\text { (lime+lemon) }\end{array}$ & $6.9 \pm 0.6 a$ & $6.8 \pm 0.9 \mathrm{a}$ & $6.6 \pm 0.5 a$ & $6.3 \pm 0.9 \mathrm{~b}$ & $6.5 \pm 1.4 \mathrm{c}$ & $6.3 \pm 0.8 b$ & $5.7 \pm 0.9 \mathrm{~b}$ & $5.2 \pm 0.4 c$ & $6.8 \pm 1.1 \mathrm{a}$ & $5.9 \pm 0.8 \mathrm{~b}$ & $5.8 \pm 0.7 \mathrm{c}$ & c $6.5 \pm 0.7 \mathrm{~b}$ \\
\hline $\begin{array}{c}\text { Kunun } \\
\text { tamba }+5 \mathrm{ml} \\
\text { (lime+lemon) }\end{array}$ & $6.7 \pm 0.5 a$ & $6.8 \pm 0.7 \mathrm{a}$ & $6.8 \pm 0.9 a$ & $6.9 \pm 0.7 \mathrm{a}$ & $6.9 \pm 1.2 \mathrm{a}$ & $6.6 \pm 0.1 \mathrm{a}$ & $6.8 \pm 0.4 \mathrm{a}$ & $6.8 \pm 0.6 \mathrm{a}$ & $6.9 \pm 0.8 \mathrm{a}$ & $6.6 \pm 1.4 a$ & $6.7 \pm 0.4 \mathrm{a}$ & a $6.7 \pm 0.2 \mathrm{a}$ \\
\hline $\begin{array}{l}\text { Kunun tamba } \\
+10 \text { ml-lemon } \\
\end{array}$ & $6.70 .4 a$ & $6.7 \pm 0.6 \mathrm{a}$ & $6.8 \pm 0.3 a$ & $6.6 \pm 0.9 \mathrm{~b}$ & $6.7 \pm 0.9 c$ & $6.4 \pm 0.2 b$ & $5.7 \pm 0.1 b$ & $6.7 \pm 0.4 \mathrm{a}$ & $5.9 \pm 0.6 b$ & $5.4 \pm 0.6 c$ & $5.5 \pm 1.3 \mathrm{~d}$ & $\mathrm{~d} 6.3 \pm 0.1 \mathrm{~b}$ \\
\hline $\begin{array}{c}\text { Kunun tamba } \\
+5 \mathrm{ml} \text {-lime }\end{array}$ & $6.9 \pm 0.9 a$ & $6.6 \pm 0.5 \mathrm{a}$ & $6.9 \pm 0.7 \mathrm{a}$ & $6.9 \pm 0.4 \mathrm{a}$ & $6.7 \pm 0.8 \mathrm{~b}$ & $6.3 \pm 0.6 b$ & $5.9 \pm 0.3 b$ & $5.7 \pm 0.6 b$ & $5.8 \pm 0.5 b$ & $5.8 \pm 0.8 b$ & $6.4 \pm 0.6 \mathrm{~b}$ & $\begin{array}{ll}\mathrm{b} & 6.4 \pm 0.8 \mathrm{~b} \\
\end{array}$ \\
\hline
\end{tabular}

Table 8: Sensory attributes of kunun tamba treated with various preservatives during storage.

${ }^{1}$ Each value is the mean \pm standard error of 50 taste member panelist; where 7 = like extremely; 6 = like very much; $5=$ like slightly; 4 = neither like nor dislike; 3 = dislike slightly; 2 = dislike very much and $1=$ dislike extremely

${ }^{2}$ Different letters within the column are significantly different $(\mathrm{p}<0.05)$

\section{Discussion}

Microorganisms isolated from fermented 'kunun tamba' showed a diverse microbial population of lactic acid bacteria (LAB) group which included Lactobacillus plantarum, Lactococcus lactis, Leuconostoc mesenteriodes and L. pseudomesenteriodes (Table 3). A similar observation was made by other workers $[6,16]$. Efiuvwevwere \& Akoma [6] reported isolating L. plantarum, L. fermentum and Streptococcus lactis from fermenting kunun-zaki using conventional methods while Agarry, et al. [16] isolated and characterized similar LABs from kunun-zaki using the API $50 \mathrm{CH}$. LABs has been widely reported to be involved in traditional cereal fermented beverages worldwide [21] and the results of this study further confirms the dominance of LABs in fermented cereal beverages.
L. lactis, are homofermenters and they produce $100 \%$ lactic acid form the fermentation of carbohydrate which lowers the $\mathrm{pH}$ close to (4.0-4.5), while the heterofermenters (L. plantarum and Leuconostoc mesenteriodes) produces other organic compounds (acetoin, acetaldehyde, $\mathrm{H}_{2} \mathrm{O}_{2}$ ) in addition to lactic acids and this lowers the $\mathrm{pH}$ to about (3.5) and impart characteristic flavor to the fermented food.

Jafari, et al. [23] reported that the antimicrobial activities of lime and lemon used as natural preservatives in fermented beverage are known to block the enzyme activities of these microorganisms. Such was evident in the results obtained in this study as the combinations of lime and lemon $(5 \mathrm{ml})$ showed a lower LAB counts $\left(\log _{10} 0.86-1.25\right)$, low $\mathrm{pH}$ (3.904.08) and higher sensory quality acceptability (taste: 6.76.9; appearance: 6.6-6.9; aroma: 6.1-6.8) throughout the 


\section{Food Science \& Nutrition Technology}

study period (4 week) where this product was rated 'like very much' (6) in all the quality attributes evaluated (Table 8). Since sensory evaluation is a simple but quick analytical tool used to ensure that the consumer gets a non-defective and enjoyable product [20], therefore, the high acceptability of the kunun-tamba treated with $5 \mathrm{ml}$ lime +lemon at the end of storage period is an indication that the combination of this natural preservatives gave the product shelf stability and hence a suitable good alternative to the artificial preservatives currently in use of which recently, consumers have been clamoring for [13].

The crude protein content of kunun tamba generally was low $(1.62-1.83 \%)$, it is of interest to note that this range is relatively higher than the $1.1-1.3 \%$ reported by Agarry, et al. [16] in kunun-zaki produced from pearl millet. Also, the carbohydrate content of kunun tamba was relatively very low compared to that of other kununs' which makes it a healthier drink for all age type. It has been reported that fermentation improves the mineral content of cereal based foods due to the breakdown of phytic acid which binds minerals in cereals and make them unavailable [24], making kunun tamba a very nutritious drink. Results obtained in this study demonstrated the possibility of producing quality fermented beverage (kunun tamba) using finger millet grain (Eleucine coracana) as it is a rich alternative to most widely grown pearl millet commonly used in fermented beverage production, finger millet is especially rich in calcium, potassium and manganese [1].

\section{References}

1. Chandra D, Chandra S, Sharma PAK (2016) Review of finger millet (Eleusine coracana L, Gaertn): A power house of health benefiting nutrients. Journal of Food Science and Human Wellness 5: 149-155.

2. Akoma 0, Agarry 00, Nkama I (2013) A study on the production and consumption pattern of 'kunun-zaki': A cereal based ethnic fermented beverage of Northern Nigeria. British Journal of Applied Sciences and Technology 3(4): 1220-1227.

3. Tamang JP (2010) Diversity of fermented foods In: Tamang JP, Kailasapathy K (Eds.), Fermented Foods and Beverages of the World. Taylor and Francis Group, New York.

4. McWilliams M (2007) Food around the World: A Cultural Perspective. Pearson Education Pub. Ltd., New Delhi.

5. Mugalavai VK, Kiam FW, Omutimba HN (2012) Using traditional cuisine contents as a channel for inter-ethnic social integration in Kenya. International Journal of Social Science Tomorrow 1(2): 1-4.
6. Efiuvwevwere BJO, Akoma O (1995) The microbiology of kunun zaki a cereal beverage from northern Nigeria during the fermentation (production) process. World Journal of Microbiology and Biotechnology 11: 491-493.

7. Akoma 0, Jiya EA, Akumka DD, Mishelia E (2006) Influence of malting on the nutritional characteristics of 'kunun zaki'. African Journal of Biotechnology 5(10): 996-1000.

8. Efiuvwevwere BJO, Akoma O (1997) The effects of chemical preservatives and pasteurisation on the microbial spoilage and shelf-life of kunun zaki. Journal of Food Safety 17(3): 203-213.

9. Inyang CU, Dabot YA (1997) Storability and portability of pasteurized and sterilized 'kunun zaki': A fermented sorghum beverage. Journal of Food Processing and Preservation 21(1): 1-7.

10. Obanewo OS, Zidon G (2003) Production and evaluation of powered kunun zaki using the fluidized bed dryer. Nigerian Food Journal 21: 144-146.

11. Nkama I, Agarry OO, Akoma 0 (2010) Sensory and nutritional quality characteristics of powdered kunun zaki (a Nigerian fermented cereal beverage). African Journal of Food Science 4(6): 364-370.

12. Campelo MCS, Medeiros JMS, Silvia JBA (2019) Natural products food preservation. International Food Research Journal 26(1): 41-46.

13. Thielmann J, Kohnen S, Hauser C (2017) Antimicrobial activity of Olea europaea, Linne extracts and their applicability as natural food preservatives agents. International Journal of Food Microbiology 251: 48-66.

14. Fapohunda SO, Adeware A (2012) Microbial load and keeping quality of kunu under various preservative regimes. Journal of Nutrition and Food Science 2(4): 1-4.

15. Akoma OSA, Onuoha MO, Ajiboye AO, Akoma and A. M. Alawoki (2002). The nutritional and sensory quality characteristics of kunun zaki produced with the addition of hydrolytic enzymes from malted rice (Oryza sativa). Journal of Food Technology in Africa 7(1): 24-26.

16. Agarry 00, Nkama I, Akoma $O$ (2010) Production of Kunun-zaki (a Nigerian fermented cereal beverage) using starter culture. International Research Journal of Microbiology 1(2): 018-025.

17. Kim JS, Lee GG, Kim J, Kwon JY, Kwon ST (2008) The development of rapid real-time PCR detection system for Vibro parahaemolyticus in raw oyster. Letters in Applied Microbiology 46(6): 649-654. 
18. Field MC (1977) Laboratory Manual in Food Preservation. AVI Pub. Co., Inc. Westport. pp: 2-10.

19. AOAC (1990) Official Methods of Analysis $15^{\text {th }}$ (Edn.), Association of Official Analytical Chemists, Washington DC, pp: 17-155.

20. Stone H, Sidel JL (2004) Sensory Evaluation Practices $3^{\text {rd }}$ (Edn.), Elsevier Academic Press, London.

21. Adnan AF, Tan IKP (2007) Isolation of lactic acid bacteria from Malaysian foods and assessment of the isolates for industrial potential. Journal of Bioresource and Technology 98(7): 1380-1385.
22. Steinkraus KH (2002) Fermentation in world food processing. Comprehensive Reviews in Food Science and Food Safety 1: 23-28.

23. Jafari S, Esfahani S, Fazeli MR, Jamalifar H, Samadi M (2011) Antimicrobial activity of lime essential oil against food borne pathogens isolated from cream-filled cakes and pastries. International Journal of Biology and Chemistry 5: 58-65.

24. Fellows PJ (2000) Food Processing Technology: Principles and Practice $2^{\text {nd }}$ (Edn.), Woodhead Pub. Ltd., Cambridge, England, pp: 170-187. 